\title{
Application of thermal analysis methods in researches of polyamide, coal fuels and their composites
}

\author{
Agnieszka Kijo-Kleczkowska ${ }^{1 *}$, Adam Gnatowski ${ }^{2 *}$, Magdalena Szumera ${ }^{3}$, Dariusz Kwiatkowski ${ }^{2}$ \\ ${ }^{1}$ Czestochowa University of Technology, Department of Thermal Machinery, Faculty of Mechanical Engineering and \\ Computer Science, Armii Krajowej 21, 42-201 Czestochowa, Poland \\ ${ }^{2}$ Czestochowa University of Technology, Department of Technology and Automation, Faculty of Mechanical Engineering \\ and Computer Science, Armii Krajowej 21, 42-201 Czestochowa, Poland \\ ${ }^{3}$ AGH University of Science and Technology, Department of Ceramics and Refractories, Faculty of Material Science and \\ Ceramics, A. Mickiewicza 30, 30-059 Krakow, Poland \\ "Corresponding authors: e-mail: gnatowski@ipp.pcz.pl; kijo@imc.pcz.czest.pl
}

This paper presents an analysis of DSC/TG/DTG thermal studies for PA6 polyamide, coal fuels and polyamide composites with these materials. The test results are aimed at comparing the thermal effects and behavior of these materials under high temperature conditions and are the basics to know of the creation and use of polymer composites with various coal fillers.

Keywords: Thermal analysis methods, polyamide, coal fuels, composites.

\section{INTRODUCTION}

The development of civilization, on the one hand, requires continuous improvement of industrial technologies, and on the other hand, it is associated with the production of an increasing amount of various types of waste. The research work of the authors of the paper and the experimental research conducted by them enabled a broad diagnosis of thermal problematic, both fuel combustion, including waste neutralization (Fig. 1) $)^{1-3}$, thermomechanical properties of polymers and their composites (Fig. 2) $)^{4-8}$, as well as thermogravimetric analysis (Fig. 3), and mass spectrometry of different materials $^{3,9-11}$.

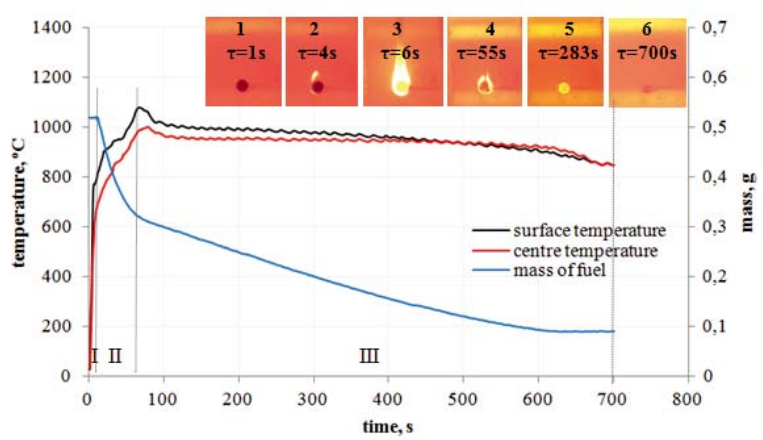

Figure 1. Visualisation of hard coal pellets combustion; changes of fuel temperature and mass during process; I-heating and evaporation (1), II devolatilisation and volatiles combustion (2-4), III-char combustion (5), $\operatorname{ash}(6)^{1}$

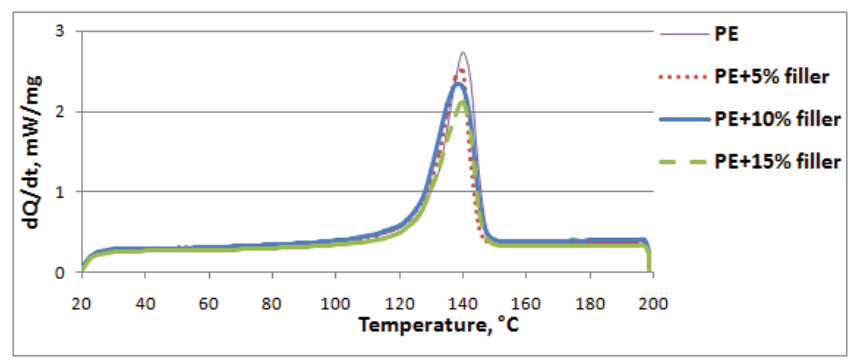

Figure 2. DSC thermograms of polyethylene modified with hard coal ash ${ }^{4}$

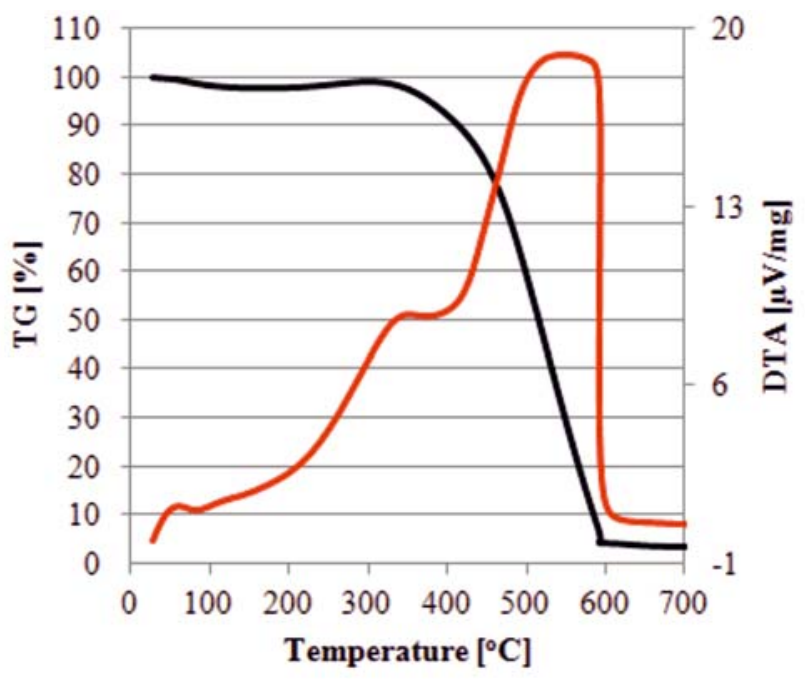

Figure 3. Curves TG-DTA of hard coal ${ }^{3}$

Polyamide PA6 is a thermoplastic construction material, partly crystalline, obtained by polycondensation of $\varepsilon$-amino caprolactam ${ }^{12}$. Due to the wide use, among others in the automotive industry, in electrical engineering, in construction and machine building, the polyamide must meet a number of requirements, including thermo-mechanical ones. It should therefore exhibit: high mechanical and fatigue strength, rigidity, hardness, dimensional stability, impact resistance, very good abrasion resistance and machinability, high heat resistance and good electrical insulating properties ${ }^{13-15}$. The properties and structure of polymers depends on the conditions of their use, e.g. from temperature, and the addition of fillers modifies the structure of polymer materials. That is why it is so important to carry out experimental research to determine the impact of the modifier type on the properties of polymer composites and their behavior under high temperature conditions.

The paper ${ }^{16}$ presents a thermal decomposition of PA6 polyamide in a helium atmosphere at a heating rate of $20^{\circ} \mathrm{C} / \mathrm{min}$. The initial, $1.5 \%$ loss of polyamide mass is associated with the release of water. Further decomposition generates the degradation of the polymer chain, leading to more than $99 \%$ loss of polyamide mass. The 
authors found two main endothermic peaks during the thermal decomposition of polyamide. The first file, at a temperature of about $220^{\circ} \mathrm{C}$, is associated with the melting of polyamide, the second - about $470^{\circ} \mathrm{C}$ - with thermal degradation of the material. It has been shown that water is released in two stages, initially from about $220^{\circ} \mathrm{C}$ to about $300^{\circ} \mathrm{C}$, which corresponds to the melting of polyamide. The temperature increase leads to the decomposition of the polyamide, associated with the release of $\mathrm{H}_{2} \mathrm{O}, \mathrm{NH}_{3}, \mathrm{CO}_{2}$, hydrocarbon fragments and $\mathrm{CO}$.

It should be emphasized that electricity production in Poland is in $86 \%$ based on hard coal and lignite. The main constituents of carbon are organic matter, mineral substance and water. The mineral substance originates from plant material. It is a mixture of various chemical compounds containing mainly $\mathrm{Ca}, \mathrm{Si}, \mathrm{Fe}, \mathrm{Al}$, $\mathrm{Mg}, \mathrm{Na}, \mathrm{K}, \mathrm{Cu}, \mathrm{P}, \mathrm{F}, \mathrm{Cl}$. The organic substance consists mainly of: coal, hydrogen, oxygen, sulfur and nitrogen as well as traces of phosphorus and other compounds. Ash is a non-combustible part of the fuel, consisting of a mineral substance. Together with moisture, it creates a fuel ballast that reduces its quality. Therefore, the calorific value of fuel decreases with the increase of the ash content. In the heating process, the organic and mineral substance of the fuel decomposes. Then moisture, numerous gases and vapors (volatiles matter) are released, leading to the formation of a $\operatorname{char}^{17-19}$.

As mentioned, under high temperature conditions, materials are subject to thermal decomposition, which is also accompanied by a change in their physical and chemical properties. Coal fuels are combusted in the presence of oxygen and undergo a number of stages of this process: heating, moisture evaporation, degassing and combustion of volatile parts and burning of the char. These stages may occur consecutively or overlap one another. In the case of coal, burning of the char is a decisive stage in the process of fuel combustion. Combustion of the char is in the simplest form a high temperature oxidation of elemental carbon to carbon dioxide. The behavior of fuels during a high-temperature process depends on their composition, thermal and flow conditions $^{17-19}$.

Combustion is also one of the main methods of thermal treatment of waste, including coal sludge. As it is known, as the quality requirements for coals burned in power plants increase, the problem of burning highly-fired fuels becomes more and more important. Hard coal mines, wanting to meet the expectations of energy engineers, were forced to expand and modernize the coal enrichment plants. This results in a continuous increase of waste in the form of post-flotation silts. The best method of utilization of these mules is their combustion in the form of suspensions and co-firing with other materials and fuels. The problem of combustion of coal sludge was taken, among others at paper ${ }^{20}$.

\section{MATERIALS AND MEASUREMENT METHODOLOGY}

The experimental studies were made for: polyamide PA6, hard coal, coal sludge, and composites polyamide PA6 (in mass of 95\%) with hard coal and coal sludge.

Polyamide 6 (PA6) under the trade name TARNAMID T-27 produced by Zakłady Azotowe Tarnów was used for the tests. The polyamide, before processing, was dried in a ZELMET dryer with a kc-100/200 heat chamber, at the temperature of $80^{\circ} \mathrm{C}$, for 12 hours. The composites were made by extrusion. The production process of the composite was carried out on the Rolbatch SJ45 computer-controlled extruder with a screw with a diameter of 45 $\mathrm{mm}$, with the following parameters: nozzle temperature $240^{\circ} \mathrm{C}$, rotation speed screw $190 \mathrm{rpm}$. The samples for testing were injected using a KRAUSS MAFFEI KM65 - 160C1 injection molding machine with a screw with a diameter of $30 \mathrm{~mm}$, and $\mathrm{L} / \mathrm{D}$ ratio $=23$, and a mold closing force of $650 \mathrm{kN}$ (Fig. 4).

The optimal properties of the tested samples were obtained with the following injection parameters:

- holding pressure: 600 bar,

- cooling time 22 sec.,

- mold temperature: $65^{\circ} \mathrm{C}$,

- nozzle temperature $240^{\circ} \mathrm{C}$.

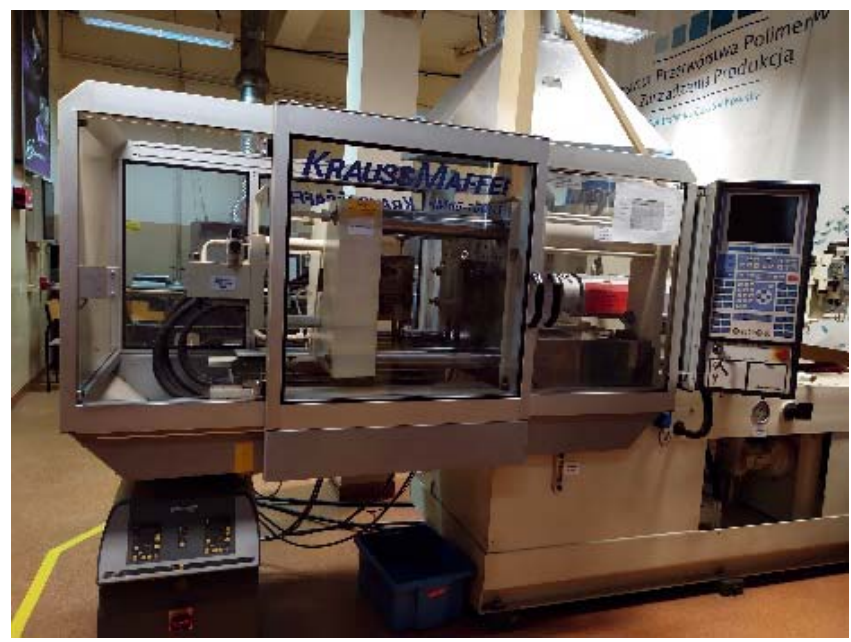

Figure 4. KRAUSS MAFFEI KM65 - 160C1 injection molding machine ${ }^{21}$

Table 1 presents proximate and ultimate analyses of researched materials. It should be noted the content of volatile matter and carbon in materials and their heating value significantly affect the thermal process.

Table 1. Proximate and ultimate analyses of the tested fuels*

\begin{tabular}{|l|c|c|c|c|c|c|c|c|c|}
\hline \multirow{3}{*}{ Fuel } & \multicolumn{4}{|c|}{ PROXIMATE ANALYSIS } & \multicolumn{4}{c|}{ ULTIMATE ANALYSIS } \\
\cline { 2 - 10 } & $\begin{array}{c}\text { Moisture } \\
\text { content }\end{array}$ & $\begin{array}{c}\text { Volatiles matter } \\
\text { content }\end{array}$ & $\begin{array}{c}\text { Ash } \\
\text { content }\end{array}$ & $\begin{array}{c}\text { Lower heating } \\
\text { value (LHV) }\end{array}$ & $\begin{array}{c}\text { Carbon } \\
\text { content }\end{array}$ & $\begin{array}{c}\text { Hydrogen } \\
\text { content }\end{array}$ & $\begin{array}{c}\text { Nitrogen } \\
\text { content }\end{array}$ & $\begin{array}{c}\text { Oxygen content } \\
\text { (calculated) }\end{array}$ & $\begin{array}{c}\text { Total sulphur } \\
\text { content }\end{array}$ \\
\cline { 2 - 10 } & $\mathrm{W}^{\mathrm{a}}$ & $\mathrm{V}^{\mathrm{a}}$ & $\mathrm{A}^{\mathrm{a}}$ & $\mathrm{Q}_{\mathrm{i}}{ }^{\mathrm{a}}$ & $\mathrm{C}^{\mathrm{a}}$ & $\mathrm{H}^{\mathrm{a}}$ & $\mathrm{N}^{\mathrm{a}}$ & $\mathrm{O}^{\mathrm{a}}$ & $\mathrm{S}_{\mathrm{c}}{ }^{2}$ \\
\hline $\begin{array}{l}\text { Hard } \\
\text { coal }\end{array}$ & 10.08 & 28.91 & 11.07 & 23.49 & 59.89 & 3.62 & 1.17 & 12.89 & 1.71 \\
\hline $\begin{array}{l}\text { Coal } \\
\text { sludge }\end{array}$ & 4.51 & 20.45 & 39.43 & 15.02 & 40.12 & 2.82 & 0.54 & 12.11 & 0.72 \\
\hline
\end{tabular}

*measurements commissioned to an external company 
The thermal characteristics of the samples were determined by differential scanning calorimetry (DSC) and thermogravimetric (TG-DTG) measurements conducted on an STA 449 F1 Jupiter (Netzsch) apparatus (Fig. 5), operating in the heat flux DSC mode, made in AGH University of Science and Technology, Faculty of Material Science and Ceramics, Department of Ceramics and Refractories. Five reference substances, i.e., indium, tin, bismuth, aluminum and gold were used for temperature and heat flow calibration. Samples weighing approx. $15 \mathrm{mg}$ were heated to $1200^{\circ} \mathrm{C}$ in $\mathrm{Al}_{2} \mathrm{O}_{3}$ crucibles at the rate of $10^{\circ} \mathrm{C} / \mathrm{min}$ in a dry air atmosphere. Good reproducibility of the DSC-TG measurements was confirmed by repeated measurements; and was approx. $\pm 0.5^{\circ} \mathrm{C}$. All the thermal parameters were calculated using the Proteus Analysis Program (Netzsch) ${ }^{\mathbf{2 2}}$.

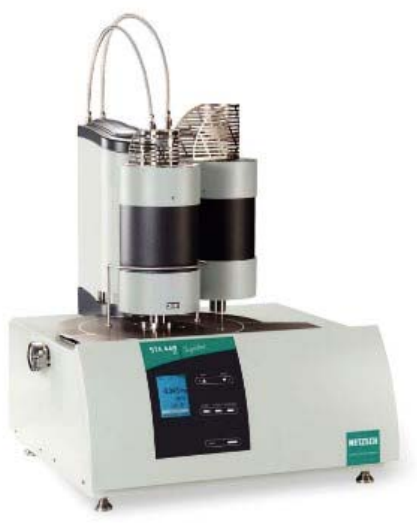

Figure 5. STA 449 F1 Jupiter (Netzsch) apparatus ${ }^{22}$

\section{ANALYSIS OF MEASUREMENT RESULTS}

Table 2 presents the analysis of results of measurements illustrated in Fig. 6-9.

Table 2. Analysis of measurements

\begin{tabular}{|c|c|c|}
\hline Material & DSC peaks; $\mathrm{T}\left[{ }^{\circ} \mathrm{C}\right]$ & Max. DTG value; $\mathrm{T}\left[{ }^{\circ} \mathrm{C}\right]$ \\
\hline PA6 & $\begin{array}{r}-0,7 \mathrm{~mW} / \mathrm{mg} ; 226{ }^{\circ} \mathrm{C} \\
1.6 \mathrm{~mW} / \mathrm{mg} ; 423{ }^{\circ} \mathrm{C} \\
3.3 \mathrm{~mW} / \mathrm{mg} ; 459{ }^{\circ} \mathrm{C} \\
2.4 \mathrm{~mW} / \mathrm{mg} ; 486{ }^{\circ} \mathrm{C}\end{array}$ & $23.5 \% / \min . ; 455^{\circ} \mathrm{C}$ \\
\hline Hard coal & $\begin{array}{c}-0.3 \mathrm{~mW} / \mathrm{mg} ; 100{ }^{\circ} \mathrm{C} \\
2.6 \mathrm{~mW} / \mathrm{mg} ; 340{ }^{\circ} \mathrm{C} \\
10.6 \mathrm{~mW} / \mathrm{mg} ; 528{ }^{\circ} \mathrm{C} \\
10.8 \mathrm{~mW} / \mathrm{mg} ; 554{ }^{\circ} \mathrm{C}\end{array}$ & $7.7 \% / \min . ; 491^{\circ} \mathrm{C}$ \\
\hline Coal sludge & $\begin{array}{r}-0.2 \mathrm{~mW} / \mathrm{mg} ; 100^{\circ} \mathrm{C} \\
2.1 \mathrm{~mW} / \mathrm{mg} ; 320^{\circ} \mathrm{C} \\
5.2 \mathrm{~mW} / \mathrm{mg} ; 410^{\circ} \mathrm{C} \\
6.1 \mathrm{~mW} / \mathrm{mg} ; 452{ }^{\circ} \mathrm{C}\end{array}$ & $3.5 \% / \min . ; 456{ }^{\circ} \mathrm{C}$ \\
\hline $\begin{array}{l}\text { PA6 }(95 \%) \\
+ \text { Hard coal } \\
(5 \%)\end{array}$ & $\begin{array}{r}-0.6 \mathrm{~mW} / \mathrm{mg} ; 224{ }^{\circ} \mathrm{C} \\
0.1 \mathrm{~mW} / \mathrm{mg} ; 350{ }^{\circ} \mathrm{C} \\
0.9 \mathrm{~mW} / \mathrm{mg} ; 400{ }^{\circ} \mathrm{C} \\
4.5 \mathrm{~mW} / \mathrm{mg} ; 460{ }^{\circ} \mathrm{C} \\
3.3 \mathrm{~mW} / \mathrm{mg} ; 499^{\circ} \mathrm{C}\end{array}$ & $23.3 \% / \min . ; 454{ }^{\circ} \mathrm{C}$ \\
\hline $\begin{array}{l}\text { PA6 }(95 \%) \\
+ \text { Coal sludge } \\
(5 \%)\end{array}$ & $\begin{array}{r}-0.6 \mathrm{~mW} / \mathrm{mg} ; 225^{\circ} \mathrm{C} \\
-2.8 \mathrm{~mW} / \mathrm{mg} ; 342^{\circ} \mathrm{C} \\
0.9 \mathrm{~mW} / \mathrm{mg} ; 407{ }^{\circ} \mathrm{C} \\
6.0 \mathrm{~mW} / \mathrm{mg} ; 458^{\circ} \mathrm{C} \\
2.5 \mathrm{~mW} / \mathrm{mg} ; 495^{\circ} \mathrm{C}\end{array}$ & $23.1 \% / \min . ; 451^{\circ} \mathrm{C}$ \\
\hline
\end{tabular}

Figure 6 illustrates the thermal analysis of DSC/TG/ DTG for polyamide. The characteristic DSC peaks can be seen at $226^{\circ} \mathrm{C}$ and $459^{\circ} \mathrm{C}$, associated with the melting and decomposition of the material.

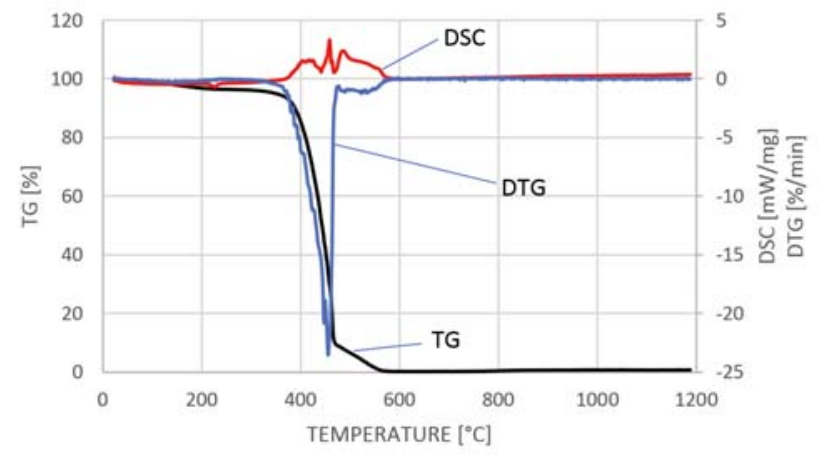

Figure 6. DSC/TG/DTG curves of PA6 (polyamide) in air

The coal sludge (Fig. 7) behaves like coal fuel during thermal processes [3]. It passes through the various stages of the process: heating, evaporation of moisture, degassing and combustion of volatiles and char combustion. The peaks on the DTG curve (adequate to the DSC peaks) correspond to the intensity of the individual process steps.

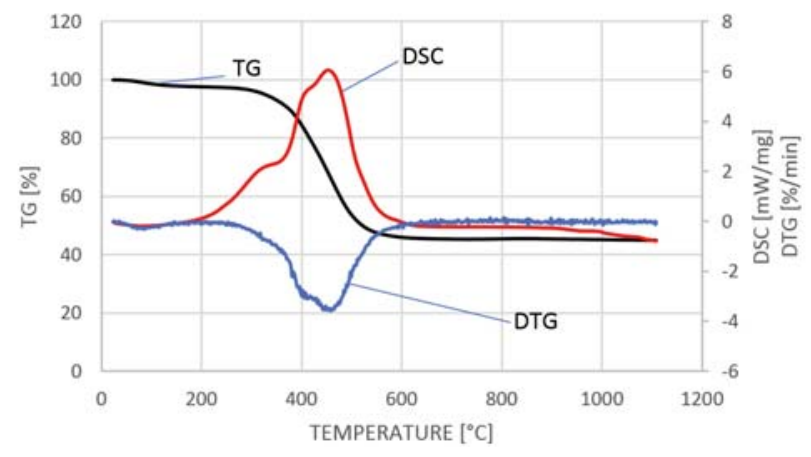

Figure 7. DSC/TG/DTG curves of coal sludge in air

Figure 8 illustrates DSC/TG/DTG thermal analysis for hard coal in air atmosphere. Coal is characterized by higher calorific value as compared to coal sludge, and higher content of carbon. During the process, therefore, more heat is released in compared to a coal sludge. The intensity of hard coal combustion is also higher compared to coal sludge.

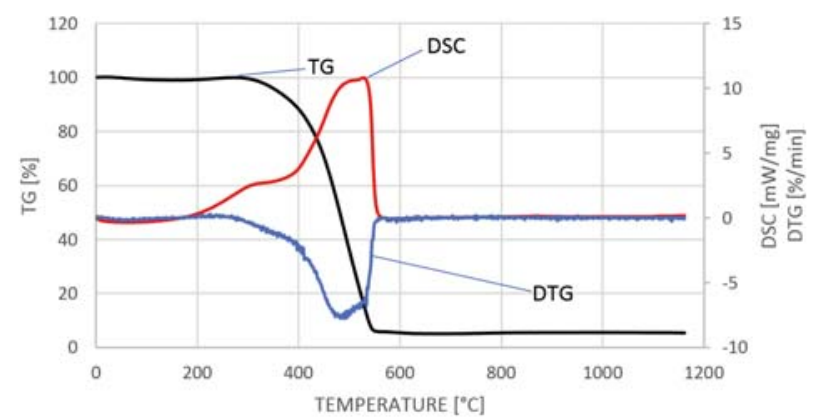

Figure 8. DSC/TG/DTG curves of hard coal in air

Figure 9 illustrates thermal analysis of DSC/TG/DTG for a sample of polyamide with coal sludge (a) and hard coal (b), with a mass fraction of $95 \%$ polyamide. In comparison to polyamide, the addition of coal sludge and hard coal to polyamide leads to an increase value 
a)

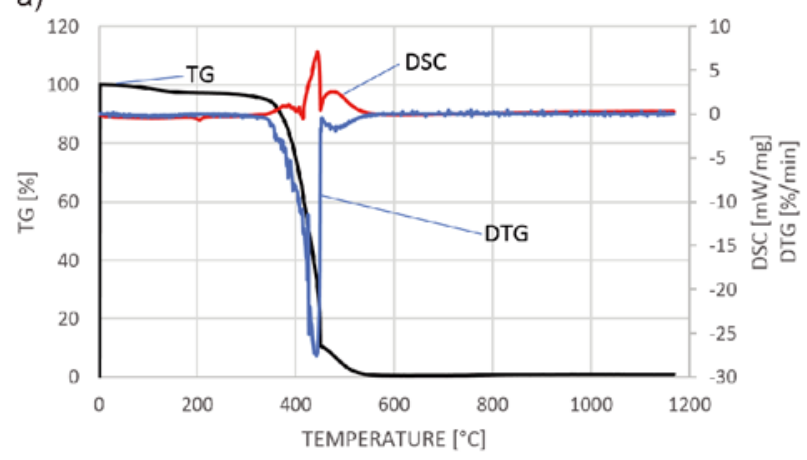

b)

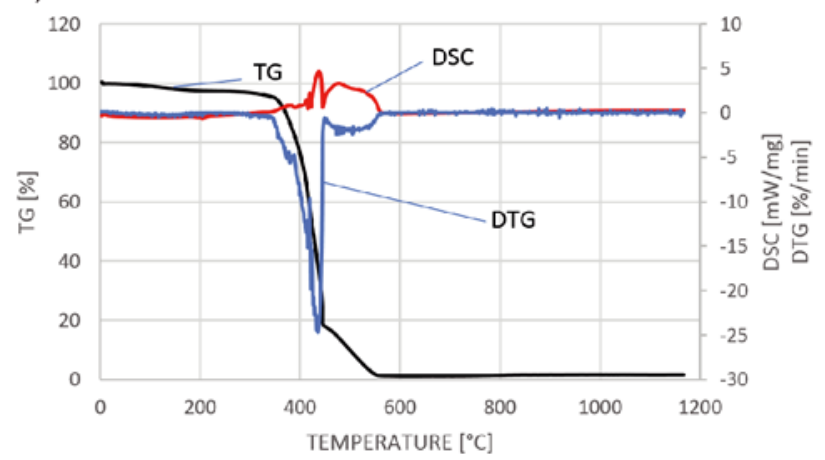

Figure 9. DSC/TG/DTG curves of sample of poliamide with coal sludge (a) and with hard coal (b), in air

of DSC peaks, which is associated with an increase in the carbon content in the tested sample.

The polyamide shows the highest rate of mass loss (DTG) and the lowest value of thermal effects during the process.

\section{CONCLUSIONS}

1. In the case of samples of polyamide and polyamide with coal sludge and hard coal, DSC peaks are observed at a temperature of about $224-226^{\circ} \mathrm{C}$, associated with the endothermic melting process.

2. Polyamide shows the most intense mass loss in the process duration $(23.5 \% / \mathrm{min})$.

3. The coal sludge and hard coal achieve higher DSC peak values compared to polyamide, which is associated with high calorific value of fuels.

4. A $5 \%$ addition of coal sludge and hard coal to polyamide leads to an increase value of DSC peaks, compared to polyamide.

\section{LITERATURE}

1. Kijo-Kleczkowska, A., Środa, K., Kosowska-Golachowska, M., Musiał, T. \& Wolski, K. (2016). Combustion of Pelleted Sewage Sludge with Reference to Coal and Biomass. Fuel 170, 141-160.

2. Kijo-Kleczkowska, A., Środa, K., Kosowska-Golachowska, M., Musiał, T. \& Wolski, K. (2015). Mechanisms and Kinetics of Granulated Sewage Sludge Combustion. Waste Management 46, 459-471.

3. Kijo-Kleczkowska, A., Łącz, A., Szumera, M. \& Środa, K. (2016). Comparative analysis of sewage sludge and other fuels and their mixes, made on the basis of thermogravimetry and mass spectrometry. Rynek energii 2 (123), 111-120.

4. Gnatowski, A. \& Kazik, E. (2019). The Research of Selected Properties and Structure of Polymeric Material Modified with Hard Coal Ash. Acta Physica Polonica A 135, 119-121.

5. Gnatowski, A. \& Sosnowski, M. (2018). Effect of PVP and Polybond Compatibilizers on Dynamic Properties of Polymer Blends Analyzed with DMTA. Adv. Sci. Technol. Res. J. 12, 36-40.

6. Gnatowski, A., Wawrzyniak, J., Chyra, M. \& Palutkiewicz, P. (2018). Examinations of the Effect of Flame Retardants on Thermal and Mechanical Properties and the Structure of Polybutylene Terephthalate. Proceedings of International Conference on Electrical, Electronics, Materials and Applied Science (red.) RAO Venkata, BEN Avinash, BHUKYA Shankar Nayak. American Institute of Physics. AIP Conference Proceedings Vol. 1952, DOI: 10.1063/1.5032055.

7. Gnatowski, A., Ulewicz, M. \& Chyra, M. (2018). Analysis of Changes in Thermomechanical Properties and Structure of Polyamide Modified with Fly Ash from Biomass Combustion. J. Polym. Environ. 26, 647-654.
8. Gnatowski, A., Kazik, E. \& Palutkiewicz, P. (2018). Investigation of Properties of Molded Parts Made of Polyethylene with Addition of Ash from Bituminous Coal. Composites Theory and Practice 18, 127-132.

9. Madej, D. (2018). Examination of dehydration and dehydroxylation of synthetic layered (oxy)hydroxides through thermal analysis (TG-DSC-EGA-MS) and a discussion to the second Pauling's rule. Inorga. Chimica Acta 482, 402-410.

10. Madej, D. \& Kruk, A. (2019). Racing the early and long-term hydration of fast setting cementitious material (Ca7ZrAl6O18Ca7ZrAl6O18) and calcium aluminate cement (CAC) pastes by means of electrochemical impedance spectroscopy and other methods, Construction and Building Materials 164, 94-102.

11. Kornaus, K., Lach, R., Szumera, M., Świerczek, K. \& Gubernat, A. (2019). Synthesis of aluminium titanate by means of isostructural heterogeneous nucleation, J. Europ. Ceramic Soc. 39, 2535-2544.

12. Plastech (2012-2019). Tworzywa, Plastechopedia, Tarnamid (PA6) - Grupa Azoty, from https://www.plastech.pl/ plastechopedia/Tarnamid-PA6-Grupa-Azoty-170.

13. Rosato, D.V., Rosato, M.G. \& Schott, N.R. (2011). Plastics Technology Handbook. Exeter, Momentum Press.

14. Pramoda, K.P. \& Liu, T. (2004). Effect of moisture on the dynamic mechanical relaxation of polyamide-6/clay nanocomposites. J. Polym. Sci., Part B: Polym. Phys. 42, 1823-1830.

15. Xie, S., Zhang, S., Wang, F., Liu, H., Yang, M. (2005). Influence of annealing treatment on the heat distortion temperature of nylon-6/montmorillonite nanocomposites. Polym. Eng. Sci. 45, 1248-1253.

16. Hornsby, P.R., Wang, J., Rothon, R., Jackson, G., Wilkinson, G. \& Cossick, K. (1996). Thermal decomposition behaviour of polyamide fire-retardant compositions containing magnesium hydroxide filler. Polymer Degradation and Stability 51, 235-249.

17. Tomeczek, J. (1992). Spalanie węgla. Wydaw. Politechniki Śląskiej, Gliwice.

18. Chomiak, J. (1977). Podstawowe problemy spalania. PWN, Warszawa.

19. Kordylewski, W. (2005). Spalanie i paliwa. Of. Wydawnicza Politechniki Wrocławskiej, Wrocław.

20. Kijo-Kleczkowska, A. (2008-2010). Research project No N N513 309935. Mechanizm współspalania zawiesinowych paliw węglowo-wodnych z biomasą, (in Polish).

21. Kijo-Kleczkowska, A., Gnatowski, A., Szumera, M., Otwinowski, H., Kwiatkowski, D. \& Suchecki, Ł. (2019). The effect of addition of coal sludge to polymeric material on thermal effects in analysis by TG/DTG/DSC methods. 6th International Conference Renewable Energy Sources, Krynica, Poland, June 12-14.

22. Netzsch. Proven Excellence (2019), from www.netzschthermal-analysis.com 